\title{
HUBUNGAN PENGUASAAN GAYA BAHASA PERBANDINGAN TERHADAP KEMAMPUAN MENULIS PUISI SISWA KELAS VII SMP DWI TUNGGAL TANJUNG MORAWA TAHUN PEMBELAJARAN 2016/2017
}

\author{
Annisa \\ Universitas Prima Indonesia, Indonesia \\ Pos-el: rindi.nisa48@gmail.com
}

\begin{abstract}
The purpose of this study is to determine the relationship of mastery of language style comparison to the students' ability in writing poetry on the seventh grade students of SMP Dwi Tunggal Tanjung Morawa in the 2016/2017 academic year. The hypothesis of this study is the mastery of the comparison language style associated with poetry writing skills. The type of this research is quantitative descriptions using correlational approach. The sample of the research is 40 people and the sampling technique is random sampling because the population is 80 people consisting of two classes and the class is homogeneous. Data were collected with multiple choice tests, and performance tests. Data were analyzed by correlation technique. Based on data analysis, there is a relationship of mastery of comparative language style to students' ability to write poetry class VII Dwi Tunggal Junior High School Tanjung Morawa year of learning 2016/2017. The students' ability to master the comparative language style gets an average score of 73.88 , then students write poetry get an average score of 72.88 . And based on calculations using the formula Product Moment correlation $\mathrm{r}$ found that the ability to master the style of language is associated significantly with the ability to write a poem with correlation coefficient 0.678 (strong correlation) $(0.678>0.312)$, so it is interpreted that the ability to master the style of language is significantly related to writing poetry .
\end{abstract}

Keywords: relationship, mastery, comparative language style, writing poetry

\begin{abstract}
Abstrak
Tujuan penelitian ini adalah untuk mengetahui hubungan penguasaan gaya bahasa perbandingan terhadap kemampuan siswa dalam menulis puisi pada siswa kelas VII SMP Dwi Tunggal Tanjung Morawa tahun pembelajaran 2016/2017. Hipotesis penelitian ini adalah penguasaan gaya bahasa perbandingan berhubungan dengan keterampilan menulis puisi. Adapun jenis penelitian ini adalah deskrifsi kuantitatif dengan menggunakan pendekatan korelasional. Sampel penelitian berjumlah 40 orang dan teknik pengambilan sampel adalahrandom sampling karena populasi berjumlah 80 orang yang terdiri dari dua kelas dan kelasnya homogen. Data dikumpulkan dengan tes pilihan ganda, dan tes unjuk kerja. Data dianalisis dengan teknik korelasi. Berdasarkan analisis data terdapat hubungan penguasaan gaya bahasa perbandingan terhadap kemampuan siswa menulis puisi kelas VII SMP Dwi Tunggal Tanjung Morawa tahun pembelajaran 2016/2017. Adapun kemampuan siswa menguasai gaya bahasa perbandingan mendapat nilai rata-rata 73,88 , selanjutnya siswa menulis puisi memperoleh nilai rata-rata 72,88. Dan berdasarkan perhitungan menggunakan rumus r korelasi Product Moment ditemukan bahwa kemampuan menguasai gaya bahasa berhubungan secara signifikan dengan kemampuan menulis puisidengan koefesien korelasi 0,678 (korelasi kuat) yakni (0,678>0,312), sehingga ditafsirkan bahwa kemampuan menguasai gaya bahasa berhubungan secara signifikan dengan menulis puisi. Kata kunci: hubungan, penguasaan, gaya bahasa perbandingan, menulis puisi
\end{abstract}




\section{PENDAHULUAN}

Berdasarkan Kurikulum Tingkat satuan Pendidikan (KTSP) 2006, pembelajaran apresiasi sastra, yaitu khususnya dalam menulis puisi ada dipelajari pada kelas VII SMP semester 1 dengan kompetensi dasar aspek menulis, standar kompetensi mengungkapkan keindahan alam dan pengalaman melalui kegiatan menulis kreatif puisiserta kompetensi dasar menulis kreatif puisi berkenaan dengan keindahan alam.

Berdasarkan pengalaman peneliti saat observasi dan wawancara dengan guru Bahasa Indonesianya di SMP Dwi Tunggal Tanjung Morawa saat belajar menulis puisi banyak sekali kesulitan yang dialami siswa saat itu. Puisi yang ditulis siswa hasilnya kurang maksimal tidak sesuai yang diharapkan dengan ketentuan KKM di sekolah tersebut. Adapun KKM untuk bidang studi Bahasa Indonesia di sekolah Dwi Tunggal Tanjung Morawa adalah 70 .

Ada beberapa kesulitan yang sering dialami siswa dalam menulis puisi yaitu, sulitnya menyesuaikan pilihan kata dengan bahasa yang sesuai tema puisi, selain itu siswa masih kurang penguasaan ungkapan-ungkapan yang mengandung makna konkrit, ketidaksesuaian bahasa yang dipakai dengan tema puisi, serta kurangnya penggunaan kata-kata konkrit ini disebabkan karena kurangnya penguasaan siswa tehadap gaya bahasa yang sering dipakai dalam penulisan sebuah puisi, sehingga bahasa yang dipakai dalam puisi hanya menggunakan bahasa denotasi saja, maka larik puisi terlihat biasa saja seperti tulisan prosa serta puisi yang dibuat tidak terdapat keindahan bahasanya. Dari kurangnya penguasaan gaya bahasa, maka puisi yang ditulis siswa kurang menarik karena tidak terdapat kata-kata konkrit dan kepadatan makna yang mendukung keindahan puisi tersebut. Kurangnya penguasaan gaya bahasa dalam penulisan puisi dapat mempengaruhi kepadatan bahasa yang digunakan dalam puisi. Kata-kata yang dituangkan dalam puisi harus padat. Kepadatan dimaksudkan untuk memberikan makna tersendiri tentang pemaknaan dari kata yang digunakan. Kepadatan bahasa yang digunakan akan memberikn warna tersendiri dalam puisi. Selain makna kepadatan juga akan menimbulkan emosi, imajinasi tersendiri bagi pembacanya. Jadi penulisan puisi patilah memerlukan gaya bahasa yang sesuai untuk menimbulkan efek tertentu bagi pembacanya. Dari hal tersebut, maka siswa perlu memahami berbagai macam gaya bahasa salah satu contohnya gaya bahasa perbandingan karena gaya bahasa perbandingan yang sering dipakai oleh pengarang dalam menulis puisi. Dengan demikian, gaya bahasa memegang peranan penting dalam penulisan puisi. Setiap pengarang pastilah menggunakan gaya bahasa tersendiri untuk menyampaikan maksud puisinya kepada pembaca. Sebagai seorang guru haruslah memeriksa bahasa-bahasa yang ditulis siswa dalam menulis puisi sesuai atau tidak dengan maksud yang hendak disampaikan.

Menurut Keraf (2006:112), gaya bahasa adalah cara penggunaan bahasa. Selanjutnya, menurut Kosasih (2006:163), gaya bahasa adalah bahasa kias, bahasa yang dipergunakan untuk menciptakan efek tertentu. Berdasarkan dari kedua pengertian di atas, dapat disimpulkan bahwa gaya bahasa dapat menilai pribadi, watak,dan kemampuan seseorang yang mempergunakan bahasa itu untuk menciptakan efek tertentu, semakin baik gaya bahasanya maka semakin baik penilaian orang terhadap puisi yang ditulis. 
Adapun fungsi gaya bahasa menurut Rais (2012: 9) menyatakan bahwa:, (1) Untuk menegaskan sesuatu dengan jelas, (2) Untuk mengulang kata atau bagian, frasa ataupun bagian dari suatu kalimat yang dirasa perlu untuk mendapatkan penekanan, (3) Untuk mengungkapkan suatu maksud atau tujuan tertentu, (4) Untuk membandingkan dua hal yang berdampingan, (4)Untuk mengumpamakan tentang sesuatu hal, dan (5) Untuk mengatakan suatu maksud tertentu dengan menggunakan kata yang berlainan maksud tertentu.

Dari pendapat di atas dapat disimpulkan bahwa setiap penggunaan gaya bahasa atau majas pastilah mempunyai maksud tertentu misalnya, menegaskan kata-kata penting, kalimat perintah, mengulang kata atau frasa yang dianggap penting yang ingin disampaikan pengarang kepada pembacanya. Dalam perbendaharaan Bahasa Indonesia dikenal berbagai jenis majas (gaya bahasa).

Menurut Rais (2012: 7) Gaya Bahasa terbagi menjadi empat macam diantaranya:(1) gaya bahasa perbandingan, (2) Gaya bahasa penegasan, (3) gaya bahasa sindiran, dan (4) gaya bahasa pertentangan. Berdasarkan masalah tersebut peneliti membahas masalah gaya bahasa perbandingan, maka hanya jenis-jenis gaya bahasa perbandingan yang akan digunakan dalam menulis puisi.Menurut Sutopo (2008:1) gaya bahasa perbandingan diantaranya ada metafora, personofokasi, asosiasi, alegori, parabel, tropen, metanomia, hiperbola, litotes, dan eufimisme. Selanjutnya Sutopo (2008:2) secara umum gaya bahasa terdiri atas gaya bahasa retoris dan gaya bahasa kiasan dan gaya bahasa yang digunakan dalam menulis puisi berupa gaya bahasa kiasan/perlambangan...jenis-jenis gaya bahasa yang digunakan pengarang dalam menulis puisi berbeda-beda sesuai dengan cerita, ciri khas pengarangnya karena gaya bahasa itu mencerminkan dari isi puisi yang disampaikan.

Sutopo (2008: 8) menyatakan bahwa"gaya bahasa dalam puisi menyebabkan sajak menjadi menarik perhatian, menimbulkan kesegaran, hidup, dan menimbulkan kejelasan gambaran angan." Bahasa kiasan yang dimaksud adalah mengiaskan antara apa yang diceritakan. Kiaskan yang dimaksud, yaitu membandingkan suatu hal atau kejadian dengan benda, menyamakan benda dengan benda lain atau menyamakan suatu kegiatan dengan benda lainnya. Hal tersebut bertujuan untuk memperjelas apa yang akan dituliskan dalam puisinya. Bahasa bahasa kiasan yang sering digunakan oleh pengarang bisanya bahasa perbandingan, yaitu gaya bahasa simili atau perumpamaan, metafora, perumpamaan, personifikasi, metonomia, sinekdok dan alegori.

Berdasarkan dari pendapat di atas dapat disimpulkan bahwa pengarang untuk menciptakan efek tertentu dalam karangannya cukup banyak dan tergantung bagaimana pengarangnya menempatkan gaya bahasa tersebut dalam karangannya. Dari sekian gaya bahasa tentu ada beberapa gaya bahasa yang paling dominan digunakan oleh pengarang dalam menulis puisi, diantaranya adalah gaya bahasa hiperbola, personifikasi, alegori, simile, metafora, sinekdoke, ironi, dan metonomia.

Puisi adalah bentuk karya sastra yang menggunakan kata-kata yang indah dan kaya makna keindahan sebuah puisi disebabkan oleh diksi, rima, dan irama yang terkandung dalam karya sastra itu. Aminudin (2010: 10) menjelaskan bahwa kemampuan seseorang dalam melakukan sebuah tulisan haruslah menguasai tema apa yang akan ditulisnnya. Selain tema juga diperlukan bahasa-bahasa yang konkrit dalam sebuah puisi. Adapun bahasa- 
bahasa konkret yang terkandung dalam puisi dikarenakan oleh pemadatan segala unsur bahasa. Bahasa yang digunakan dalam puisi berbeda dengan yang digunakan sehari-hari. Puisi menggunakan bahasa yang ringkas namun maknanya sangat kaya.Menulis puisi kegiatan yang dilakukan penyair untuk mengekspresikan pikran dan gagasannya melalui susunan kata-kata indah dan padat yang bermakna. Selanjutnya menurut Kosasih (2006) hal hal yang perlu diperhatikan dalam menulis puisi yaitu "puisi mengungkapkan diri pengarang, orang lain, dan dunia yang lain. Tema yang diangkat berdasarkan masalah atau berbagai hal yang menyentuh kesadaran pengarangnya. Cara penyampaian puisipun harus menggunakan gaya bahasa yang sesuai dengan isi puisinya. Dapat disimpulkan bahwa menulis puisi merupakan kegiatan mengekspresikan pikiran dan gagasan melalui kata-kata yang indah dengan menggunakan gaya bahasa yang sesuai ceritanya.

Kosasih (2006:206) menyatakan kata-kata yang digunakannya adalah kata-kata konotatif, yang mengandung banyak penafsiran dan pengertian. Dari pengertian di atas menulis puisi adalah menuangkan semua ide, gagasan seseorang dengan menggunakan bahasa yang padat dan pilihan kata-kata konkrit sehingga bahasanya indah sehingga pembacanya dapat memahami makna-makna tersirat di dalamnya (Aminudin, 2010: 6). Puisi tidak akan indah jika tidak terdapat kata-kata konkrit di dalamnya. Seseorang dikatakan berhasil dalam menulis puisi jika puisi yang dibuatnya menggunakan gaya bahasa yang bisa ditafsirkan oleh pembaca.

Secara garis besar, unsur-unsur terbagi kedalam dua macam, yakni struktur fisik dan struktur batin. Brikut adalah uraiannya yang banyak penulis petik dari teori dan apresiasi puisi Waluyo (1995). Dari penjelasan di atas dapat dikatakan bahwa, unsur yang terdapat dalam sebuah puisi itulah yang membangun sebuah puisi, adapun unsur puisi ada unsur fisik dan unsur batin. Adapun unsur fisik adalah unsur yang terdapat di dalam puisi tersebut. Unsur fisik meliputi (1) Diksi (pemilihan kata)Penyair yang sangat cermat dalam memilih kata-kata yang ditulis sangat dipertimbangkan maknanya, komposisinya dalam rima dan irama. Kedudukan kata itu dalam konteks atau dalam hubungan dengan kata yang lain, serta kedudukan kata dalam keseluruhan puisi itu. Oleh karena itu disamping memiliki kata yang tepat, penyair juga mempertimbangkan urutan katanya dan kekuatan atau daya magis dari kata-kata tersebut. Kata-kata diberi makna baru dan yang tidak bermakna diberi makna menurut kehendak penyair. karena begitu pentingnya kata-kata dalam puisi, maka bunyi kata juga harus dipertimbangkan secara cermat dalam pemilihannya, karena pemilihan kata mempertimbangkan berbagai aspek etis, sehingga kata-kata yang sudah dipilih oleh penyair untuk puisinya bersifat absolute dan tidak biasa diganti dengan padan katanya sekalipun maknanya itu tidak berbeda. Hendaknya disadari bahwa kata-kata dalam puisi bersifat konotatif yaitu makna yang mempunyai arti lebih dari satu. Kata-kata yang dipilih hendaknya bersifat puitis, yang mempunyai efek keindahan dan berbeda dengan kata-kata yang biasa kita pakai sehari-hari (2)Pengimajian, Pengimajian dapat didefinisikan sebagai kata atau susunan kata yang dapat mengungkapkan pengalaman imajinasi. Dengan daya imajinasi yang diciptakan penulis. Selanjutnya ada empat unsur batin puisi, yakni tema (sense), perasaan penyair (feeling), nada atau sikap penyair terhadap pembaca (tone) dan amanat(intention) (Aminudin, 2010: 15) (1)Tema dan Amanat tema dan amanat merupakan bagian dari struktur batin puisi. Tema adalah pokok persoalan yang akan diungkapkan oleh 
penyair. (2) Perasaan, perasaan adalah bentuk ekspresi pengarang terhadap isi ceritanya, dapat berupa kerinduan, kegelisahan atau pengagungan kepada kekasih, kepada alam, atau sang khalik. (3) Nada dan Suasana, nada merupakan sikap penyair terhadap pembaca, maka suasana adalah keadaan jiwa pembaca setelah membaca puisi itu atau akibat psikologis akibat yang ditimbulkan puisi itu terhadap pembaca.

Berdasarkan dari beberapa permasalahan penyebab kurangnya penguasaan tentang gaya bahasaperbandingan siswa terhadap kemampuan menulis puisi adalah pertama bagaimanakah penguasaan gaya bahasa perbandingan pada Siswa kelas VII SMP Dwi Tunggal Tanjung Morawa Tahun Pembelajaran 2016/2017?Kedua, bagaimanakah kemampuan menulis puisi pada Siswa Kelas VII SMP Dwi Tunggal Tanjung Morawa Tahun Pembelajaran 2016/2017? Ketiga, bagaimanakah hubungan penguasaan gaya bahasa perbandingan terhadap kemampuan menulis puisi pada siswa kelas VII SMP Dwi Tunggal Tanjung Morawa Tahun Ajaran 2016/2017?

Berdasarkan rumusan masalah tersebut maka tujuan penelitian ini adalah pertama, untuk mengetahui penguasaan gaya bahasa perbandingan Siswa Kelas VII SMP Dwi Tunggal Tanjung Morawa Tahun Pembelajaran 2016/2017. Kedua, untuk mengetahui kemampuan menulis puisi siswa Kelas VII SMP Dwi Tunggal Tanjung Morawa Tahun Pembelajaran 2016/2017. Ketiga, untuk mengetahui hubungan penguasaan gaya bahasa perbandingan terhadap kemamapuan menulis puisi siswa Kelas VII SMP Dwi Tunggal Tanjung Morawa Tahun Pembelajaran 2016/2017.

\section{METODE PENELITIAN}

Penelitian ini menggunakan metode deskriptif korelasional. Metode ini digunakan dalam penelitian karena mengingat data yang dibutuhkan sudah ada (melekat pada sampel) sehingga penelitian bertujuan untuk menggambarkan kadar hubungan (korelasi) data-data yang diinginkan. Adapun Populasi dalam penelitian ini adalah seluruh Siswa Kelas VII SMP Dwi Tunggal Tanjung Morawa Tahun Pembelajaran 2016/2017, berjumlah 80 orang dan terbagi dalam 2kelas. Selanjutnya yang dijadikan sampel penelitiannya adalah satu kelas saja, yaitu kelas VII- A yang terdiri dari 40 siswa. Sampel penelitian diambil dengan cara random sampling. Selanjutnya cara menjaring data penguasaan gaya bahasa perbandingan digunakan tes obyektif (pilihan ganda) dengan empat jawaban, dan hanya disediakan satu jawaban yang benar. Jumlah soal yang digunakan adalah untuk menjaring data penguasaan gaya bahasa perbandingan sebanyak 40 soal. Jika siswa mampu menjawab satu butir soal maka diberikan skor 2,5, namun jika siswa tidak dapat menajwab satu butir soal dengan benar diberi skor 0 . Waktu yang diberikan untuk menjawab soal 30 menit.

Data Kemampuan menulis puisi di jaring dengan melakukan tes. Tes terrsebut disusun berdasarkan dari kompetensi dasar dan indikator pada materi menulis puisi yaitu siswa mampu menentukan tema puisi yang akan dibuat, siswa mampu mendaftar kata-kata sifat benda yang akan ditulis dalam sebuah puisi, dan siswa mampu menyusun kata sifat, kata kerja dengan menggunakan bahasa yang indah dan dituangkan menjadi sebuah puisi. Berdasarkan indikator pembelajaran tersebut, peneliti mengembangkan tes menulis puisi dengan memperhatikan syarat-syarat penulisan puisi yaitu:menentukan tema puisi, 
menentukan kata-kata sifat yang disesuaikan dengan tema puisi, penggunaan rima, irama, nada dan suasana puisi dan diksi yang digunakan. Adapun aspek-aspek yang dinilai dari penulisan puisi adalah bahasa judul puisi, gaya bahasa yang digunakan, rima dan irama, terdapat kata konkrit dalam puisi, pesan puisi, tifografi bait puisi,dan nada suasana puisi.

\section{HASIL DAN PEMBAHASAN}

Data dalam penelitian ini berupa skor yang diperoleh melalui lembaran tentang objektif tentang penguasaan gaya bahasa perbandingan serta tes keterampilan menulis puisi. Dengan demikian data penelitian ini dikelompokan menjadi dua kelompok yaitu satu kelompok data terkait dengan variabel terikat $\mathrm{Y}$ dan satu kelompok variabel bebas $\mathrm{X}$. Kedua data tersebut didikripsikn ke dalam bentuk ditribusi frekuensi, uji homogenitas, uji liniearitas, dan uji korelasi.

Tabel 1. Distribusi Frekuensi Nilai Kemampuan Menguasai Gaya Bahasa Perbandingan(X)

\begin{tabular}{|c|c|c|c|c|c|}
\hline No & $\begin{array}{c}\text { Interval } \\
\text { Nilai }\end{array}$ & Kategori & Frekuensi & $\%$ & Keterangan \\
\hline 1 & $80-100$ & $\begin{array}{c}\text { Baik } \\
\text { sekali }\end{array}$ & 12 & 30 & Tuntas \\
\hline 2 & $66-79$ & Biak & 18 & 45 & Tuntas \\
\hline 3 & $56-65$ & Cukup & 9 & 22,5 & $\begin{array}{c}\text { Tidak } \\
\text { Tuntas }\end{array}$ \\
\hline 4 & $40-55$ & Kurang & 1 & 2,5 & Tidak tuntas \\
\hline 5 & $30-39$ & Gagal & 0 & 0 & Tidak tuntas \\
\hline & Jumlah & & 40 & 100 & \\
\hline
\end{tabular}

Berdasarkan dengan tabel distribusi frekuensi nilai kemampuan menguasai gaya bahasa perbandingan dapat disimpulkan bahwa yang berada di rentang nilai anatara 80-100, yaitu 12 orang dengan ketuntasan 30\% dengan kategori baik sekali, rentang nilai 66-79 dengan kategori baik 18 orang dengan 45\% tuntas,rentang 56-65 dengan kategori cukup 9 orang dinyatakan tidak tuntas, dan kategori gagal hanya 1 orang dan dinyatakan 2,5\% tidak tuntas. Maka dengan demikian dapat disimpulkan didapatkan persentase tinggi yang menguasai gaya bahasa perbandingan berada dalam kategori baik, sehingga disimpulkan kemempuan siswa menguasai gaya bahasa cenderung baik.

Tabel 2. Distribusi Frekuensi Nilai Kemampuan Menulis Puisi (Y)

\begin{tabular}{|c|c|c|c|c|c|}
\hline No & Interval Nilai & Kategori & Frekuensi & $\%$ & Keterangan \\
\hline 1 & $80-100$ & Baik sekali & 10 & 25 & Tuntas \\
\hline 2 & $66-79$ & Biak & 27 & 42,5 & Tuntas \\
\hline 3 & $56-65$ & Cukup & 3 & 32,5 & Tidak Tuntas \\
\hline 4 & $40-55$ & Kurang & 0 & 0 & Tidak tuntas \\
\hline 5 & $30-39$ & Gagal & 0 & 0 & Tidak tuntas \\
\hline & Jumlah & & 40 & 100 & \\
\hline
\end{tabular}


Berdasarkan tabel di atas untuk kategori 80-100 dengan kategori baik sekali10 orang dan tuntas dengan kategori baik sekitr 27 orang. Selanjutnya persentase tertinggi berada dalam kategori baik, sehingga disimpulkan kemampuan siswa menulis puisi cenderung baik.

Tebel. 3. Distribusi Frekuensi untuk Mencari Mean dan StandarDeviasi Kemampuan Menguasai Gaya BahasaPerbandingan (X)

\begin{tabular}{|c|c|c|c|c|}
\hline$X_{1}$ & $F_{1}$ & $X_{1}{ }^{2}$ & $F_{1} X_{1}$ & $F_{1} X_{1}{ }^{2}$ \\
\hline 55 & 1 & 3025 & 55 & 3025 \\
\hline 60 & 2 & 3600 & 120 & 7200 \\
\hline 65 & 7 & 4225 & 455 & 29575 \\
\hline 70 & 10 & 4900 & 700 & 49000 \\
\hline 75 & 8 & 5625 & 600 & 45000 \\
\hline 80 & 5 & 6400 & 400 & 32000 \\
\hline 85 & 3 & 7225 & 255 & 21675 \\
\hline 90 & 2 & 8100 & 180 & 16200 \\
\hline 95 & 2 & 9025 & 190 & 18050 \\
\hline$\sum$ & 40 & 52125 & 2955 & 221725 \\
\hline
\end{tabular}

Berdasarkan tabel di atas dapat diketahui nilai rata-rata dan standar deviasi kemampuan menguasai gaya bahasaperbandingan dan mean kemampuan menguasai gaya bahasa perbandingan (variabel X) adalah 73,88 kategori B (baik) dan standar deviasi kemampuan menguasai gaya bahasa (variabel X) adalah 9,40.

Tabel.4. Distribusi Frekuensi untuk Mencari Mean dan Standar Deviasi Kemampuan Menulis Puisi $(Y)$

\begin{tabular}{|c|c|c|c|c|}
\hline 1 & 1 & $\mathbf{1}^{2}$ & $\boldsymbol{F}_{1} X_{\mathbf{1}}$ & $\boldsymbol{F}_{\mathbf{1}} \boldsymbol{X}_{\mathbf{1}}{ }^{2}$ \\
\hline 60 & 5 & 3600 & 300 & 18000 \\
\hline 65 & 8 & 4225 & 520 & 33800 \\
\hline 70 & 9 & 4900 & 630 & 44100 \\
\hline 75 & 8 & 5625 & 600 & 45000 \\
\hline 80 & 3 & 64000 & 240 & 19200 \\
\hline 85 & 3 & 7225 & 255 & 21675 \\
\hline 90 & 2 & 8100 & 180 & 16200 \\
\hline 95 & 2 & 9025 & 190 & 18050 \\
\hline$\sum$ & 40 & 49100 & 2955 & 221725 \\
\hline
\end{tabular}

Berdasarkan tabel di atas dapat diketahui nilai rata-rata dan standar deviasi sebagai berikut: Mean kemampuan menulis puisi (variabel Y) adalah 72,88 kategori B (baik) dan standar deviasi kemampuan menulis puisi (variabel Y) adalah 9,60.

Selanjutnya untuk mengetahui apakah penguasaan gaya bahasa perbandingan berhubungan signifikan atau tidak maka diuji terlebih dahulu homogenitas, liniearitas, dan korelasinya. 


\section{Uji Homogenitas}

Homogenitas data yang dilakukan untuk mengetahui sampel yang digunakan dalam penelitian apakah homogen atau tidak dan apakah sampel yang dipakai dalam penelitian ini dapat mewakili seluruh populasi yang ada. Perhitungan data diperoleh:

$$
\begin{aligned}
\bar{X}=73,88 ; \mathrm{SD}=9,40 ; \mathrm{SD}^{2}=88,36 ; \mathrm{N}=40 \\
\bar{Y}=72,88 ; \mathrm{SD}=9,60 ; \mathrm{SD}^{2}=92,16 ; \mathrm{N}=40, \text { maka, } \\
\mathrm{F}=\frac{V \quad t}{V} \quad T \\
\mathrm{~F}=\frac{9,1}{8,3} \\
\mathrm{~F}=1,04
\end{aligned}
$$

Harga $F_{\text {hit }}$ dibandingkan dengan $F_{t} \quad$ diperoleh $L_{\text {hit }} \quad$ atau 1,04 $<1,80$ sehingga sampel berasal dari kelompok dalam penelitian ini dinyatakan homogen. Artinya, data diperoleh dapat mewakili seluruh populasinya.

\section{Uji Liniearitas}

Uji liniearitas bertujuan untuk mengetahui apakah dua variabel mempunyai hubungan yang linier atau tidak secara signifikan. Adapun dari hasil uji linieraitas dapat dihasilkan bahwa nilai kritik sebaran $F$ dengan taraf signifikan $\propto=0,05$ dan $\mathrm{dk}=\mathrm{n}-2$ di dapat $F_{t_{1}}=4,12$. Dari hasil perhitungan didapat $F_{h} \leq F_{t_{1}}$ atau 31,95 $\geq 4,12$ karena $\mathrm{F}_{\mathbf{h}} \leq F_{t_{1}} \quad$ maka Ha diterima dan Ho ditolak. Dengan demikian terdapat hubungan yang signifikan penguasaan gaya bahasa perbandingan dengan kemampuan menulis puisi siswa kelas VII SMP Dwi Tunggal Tanjung Morawa Tahun Pembelajaran 2016/2017.

\section{Uji Korelasi}

Uji korelasi bertujuan untuk mengetahui adanya hubungan antara penguasaan gaya bahasa perbandingan dengan kemampuan menulis puisi. Berdasarkan perhitungan didapat koefesien kerelasi 0,678 menurut Sugiono (2008) berada pada rentangan 0,600-0,799 ditafsirkan korelasi kuat. Berdasrkan indeks korelasi ini, signifikasinya akan diuji. Pengujian dilakukan dengan jalan mengonsultasikannya harga $r_{h}$ dengan harga $r_{t_{i}}$ product moment pada derajat kebebasan $(\mathrm{db})=40$ dengan taraf signifikasi $5 \%$ atau $\propto=0,05$ dengan $\mathrm{db}=40$ diperoleh harga $\mathrm{r}_{\mathbf{t}_{\mathbf{i}}} \quad$ pada taraf signifikasi 95\% adalah 0,312. Jadi $\mathbf{r}_{\mathbf{h}} \quad>\mathbf{r}_{\mathbf{t}_{\mathbf{t}}}$ $(0,678>0,312)$, sehingga dapat ditafsirkan penguasaan gaya bahasa perbandingan berhubungan dengan kemampuan menulis puisi, maka semakin tinggi kemampuan menguasai gaya bahasa perbandingan maka semakin tinggi kemapuan menulis puisi. Besar kecilnya pengaruh variabel $\mathrm{X}$ terhadap variabel $\mathrm{Y}$ berikut ini diukur dengan besar kecilnya koefesien determinasi yang diperoleh. Koefesien determinasi mengandung arti bahwa besarnya persentase varians variabel yang satu ditentukan oleh varians lain. Dengan demikian, perhitungan koefesien detreminasi sebagai berikut, berdasarkan data diperoleh,

$$
\begin{aligned}
& \mathrm{B}=0,69 \quad \sum \mathrm{X}=2955 \\
& \sum Y=2915=\sum Y^{2}=216025 \sum X Y=217725 \\
& \text { Maka: } \\
& \mathrm{r}^{2}=\frac{b\left\{n \sum X-\left(\sum X\right)(X)\right\}}{n \sum \mathrm{Y}^{2}-\left(\sum Y\right)^{2}}
\end{aligned}
$$

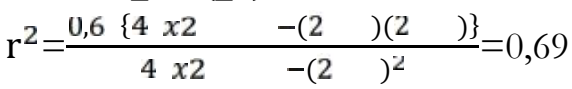


SeBaSa: Jurnal Pendidikan Bahasa dan Sastra Indonesia

Persentase Determinasi $=0,69 \times 100 \%=69 \%$

Hasil koefesien determinasi adalah $69 \%$ yang menginterminasikan bahwa kemampuan menguasai gaya bahasa berpengaruh sebesar 69\% terhadap kemampuan menulis puisi dan 31\% dipengaruhi oleh faktor lain di luar kemampuan menguasai gaya bahasa perbandingan pada siswa kelas VII SMP Dwi Tunggal Tanjung Morawa tahun Pembelajaran 2016/2017.

\section{Hubungan Penguasaan Gaya Bahasa Perbandingan dengan Keterampilan Menulis Puisi}

Penelitian ini adalah penelitian korelasi. Teknik yang digunakan dengan membuat suatu analisis statistik, menggunakan uji korelasi $\mathrm{r}$ Product Moment sederhana. Untuk menguji hipotesis digunakan taraf signifikan $=0,05$ tingkat kekeliruan sebesar 5\%. Dari hasil yang dianalisis yang dilakukan maka kemampuan menguasai gaya bahasa perbandingan berhubungan dengan kemampuan menulis puisi.

Kemampuan menguasai gaya bahasaperbandingan dikategorikan B (baik), sebab siswa dapat memahami tema, nadan perasaan dan amanat suatu puisi baiknya nilai pada aspek ini disebabkan penguasaan mengenai konsep puisi dapat dipahami oleh siswa.

Sama halnya dengan kemampuan menguasai gaya bahasa perbandingan, maka kemampuan menulis puisi siswa juga dikategorikan B (baik), sebab dalam puisi yang dihasilkan sudah mengandung satu pokok permasalahan, pokok persoalan tersebut sesuai dengan tema yang ditentukan, dan maksud yang disampaikan sudah tepat hubungannya dengan tema. Penggunaan diksi sudah tepat dalam menyampaikan maksud puisi sehingga penggambaran imajinasi terlihat nyata, artinya, siswa dapat menguasai gaya bahasa perbandingan.

Besar pengaruh kemampuan menguasai gaya bahasa perbandingan terhadap kemampuan menulis puisi melalui perhitungan koefesien determinasi sebesar $69 \%$. Hasil ini menunjukan bahwa menguasai gaya bahasa perbandingan merupakan faktor penentu dalam meningkatkan kemampuan menulis puisi. Hal ini dibuktikan hasil penelitian bahwa kemampuan menguasai gaya bahasa perbandingan berhubungan secara signifikan dengan kemampuan menulis puisi.

Selain kemampuan menguasai gaya bahasa perbandingan, masih ada lagi kemungkinan faktor-faktor lain yang mempengaruhi kemampuan menulis puisi, misalnya kebiasaan membaca dan mengappresiasikan puisi, motivasi belajar puisi, metode pembelajaran puisi, kegiatan diskusi di sekolah ataupun di luar sekolah, peranan guru dalam mengajar, faktor sarana dan prasarana, melakukan latihan yang intensif dan sebagainya, hal ini tidak diambil datanya kuantitatif, karena dalam penelitian ini hal tersebut tidak diteliti. Dengan demikian memberi kesempatan kepada peneliti lain untuk melakukan penelitian lanjutan.

Berdasarkan dari uraian di atas, penelitian terhadap siswa kelas VII SMP Dwi Tunggal Tanjung Morawa Tahun Ajaran 2016/2017 ini sudah dapat dikatakan baik sebab nilai rata-rata siswa sudah mencapai 70 sesuai dengan standar kompetensi yang terdapat di sekolah tersebut. akan tetapi, pada kondisi lain mungkin perlu perbaikan secara menyeluruh karena pada penelitian ini tidak terpantaunya keseriusan siswa menjawab materi tes. 
Artinya, dalam menguasai gaya bahasa dan menulis puisi, boleh jadi siswa tidak atau kurang serius sehingga penelitian ini banyak kekuranganya.

Berdasarkan hasil penelitian ini, maka siswa masih mebutuhkan bantuan dari sekolah. Guru diharapkan berusaha terus meningkatkan kondisi pembelajaran agar siswa dapat memperoleh nilai maksimal yang diprsyaratkan dalam kurikulum. Oleh sebab itu, tidak menutup kemungkinan adanya kelemahan-kelemahan lain. Namum, hasil penelitian ini setidaknya memberikan gambaran betapa dibutuhkan penguasaan gaya bahasa jika hendak menulis puisi.

\section{SIMPULAN}

Berdasarkan teknik analisis data maka dapat disimpulkan bahwa kemampuan siswa menguasai gaya bahasa perbandingan mendapat nilai rata-rata 73,88 , selanjutnya siswa menulis puisi memperoleh nilai rata-rata 72,88. Dan berdasarkan perhitungan menggunakan rumus r korelasi Product Moment ditemukan bahwa kemampuan menguasai gaya bahasa perbandingan berhubungan secara signifikan dengan kemampuan menulis puisidengan koefesien korelasi 0,678 (korelasi kuat) yakni-----(0,678>0,312), sehingga ditafsirkan bahwa kemampuan menguasai gaya bahasa perbandingan berhubungan secara signifikan dengan menulis puisi. Artinya kemmapuan menguasai gaya bahasa, maka semaikn tinggi kemampuan menulis puisi. Kemampuan menguasai gaya bahasa bukan saja berhubungan secara signifikan dengan kemampuan menulis puisi tetapi turut meberikan pengaruh besar 69\% terhadap kemapuan menulis puisi. Artinya, tinggi rendahnya kemampuan siswa menulis pusisi, dapat ditentukan oleh kemampuan menguasai gaya bahasa perbandingan.

\section{DAFTAR PUSTAKA}

Aminudin. 2010. Kreatif Menulis Puisi dan Cerita Pendek. Tanggerang: Citralab Hasim, Abdul. 2013. Menganalisis Fiksi Sebuah Pengantar. Bogor: Galia Indonesia Keraf, Gores. 2006. Diksi dan Gaya Bahasa. Jakarta: Gramedia Pustaka Utama Kosasih. E. Bimbingan Pemantapan Bahasa Indonesia. 2007: Bandung: Yrama Widya Moleong, Lexy J. 2011. Metodologi Penelitian Kualitatif. Bandung: PT. Remaja Rais, Putra. 2012. Panduan Super Lengkap Majas EYD Peribahasa. Jakarta: Buku Pintar Sodiki, Mustafa. 2010. Kumpulan Sastra Indonesia : Pantun, Puisi, Majas, Peribahasa, Kata Mutiara. Jakarta: Gudang Ilmu

Sutopo, Maryati. 2008. Bahasa dan Sastra Indonesia untuk Kelas VII SMP. Medan: Madju Medan Cipta. 